\title{
Editorial
}

\section{Continuity of Maternal and Baby Antenal Care (ANC) Services during the Pandemic}

\section{Rajuddin Rajuddin}

Antenatal care is an essential part of pregnancy and is useful for detecting diseases and complications such as anemia, pre-eclampsia, gestational diabetes, asymptomatic urinary tract infections and stunted fetal growth. Pregnant women who do not receive antenatal care have a higher risk of maternal death, stillbirth, and other pregnancy complications such as viral infections. ${ }^{1,2}$ Severe acute respiratory syndrome Coronavirus 2 (SARS-CoV-2), also called Coronavirus 2019 (Covid-19), was first discovered in December 2019 in Wuhan, China and is a widespread infection. ${ }^{3}$ The gene that causes the Covid-19 disease has been dispersed globally, leading to a Covid-19 pandemic. ${ }^{4}$ Pregnant women are considered a high risk group because they are more susceptible to the possible effects of COVID-19 during pregnancy, after pregnancy, and also on their neonates. ${ }^{5}$

Results of several systematic reviews and meta-analytic studies have reported that pregnant and recently pregnant women with COVID-19 tend to not have symptoms such as fever, dyspnea or myalgia but are more likely to be admitted to the intensive care unit compared to women of reproductive age who are not pregnant. ${ }^{6}$ Preexisting maternal comorbidity such as chronic hypertension, diabetes, advanced maternal age, and high body mass index are risk factors that exacerbate COVID-19. Neonates of preterm pregnancies require further management in preterm neonate care facilities, as they at increased risk of death and being admitted to the intensive care unit. ${ }^{6}$ Certain risk factors found in pregnancy, such as Pre-eclampsia, have been reported to worsen the condition of the mothers with COVID-19, however this requires further clinical evidence. ${ }^{5}$

Pregnant women during the COVID-19 pandemic are advised to continue routine antenatal care with some modifications, except for pregnant women who require independent isolation due to suspected or confirmed COVID-19. WHO issued a recommendation for low-risk pregnant women to receive at least 8 antenatal care. During the pandemic, direct physical antenatal consultations are carried out at least 6 times for low-risk pregnant women, but in high-risk cases the frequency of antenatal care is adjusted. ${ }^{7}$ Several modifications are needed to provide adequate antenatal care to pregnant women carrying out social distancing and those who are suspected or confirmed to have COVID-19, with the aim of reducing transmission between pregnant women and medical staff. 2,7

All pregnant women with a history of contact with confirmed COVID-19 individuals are monitored carefully, considering that some cases of COVID-19 are asymptomatic. Pregnant women with suspected or confirmed COVID-19 may not require hospitalization unless there is a significant health risk. Self-isolation to contain viral transmission is recommended, and can be carried out in health facilities, community facilities or at home, in accordance with current COVID-19 management pathways. ${ }^{8}$ Supplementation of folic acid, calcium, vitamin D and micro nutrients is still given and adjusted to the needs of each pregnant woman. Provision of Iron tablets for pregnant women with suspected, probable or confirmed COVID-19 status is done with consideration of the treating doctor and the condition of the patient concerned. Antenatal care in the third trimester is performed to plan the location of the delivery. If the pregnancy is found to be high risk, a planned referral to the hospital can be arranged ahead of time. ${ }^{7}$

Should pregnant women be vaccinated? Pregnant women with COVID-19 have greater risk than women who are not pregnant. Vaccines, such as tetanus, pertussis and influenza, are safe to use during pregnancy. ${ }^{9}$ Pregnant women should have access to vaccinations and be given the choice whether to have the vaccine after being educated about its benefits and risks. Current studies suggest that COVID-19 vaccination during the preconception period does not have a negative impact, although the number of observations were limited. ${ }^{10}$ The European Society of Human Reproduction and Embryology (ESHRE) concluded that there is currently no information on the safety of different types of vaccines during pregnancy, and no recommendations can be made about which vaccine types are safest for men and women trying to conceive. ${ }^{10}$ 


\section{REFERENCES}

1. Kementerian Kesehatan RI. Buku Ajar Kesehatan Ibu dan Anak. Pusat Pendidikan dan Pelatihan Tenaga Kesehatan, Jakarta. 2015.

2. Kementerian Kesehatan RI. Pedoman Bagi Ibu Hamil, Bersalin,Nifas, dan Bayi Baru Lahir di Era Pandemi Covid-19. Direktorat Kesehatan Keluarga Direktorat Jenderal Kesehatan Masyarakat, Jakarta. 2020.

3. Zhu N, Zhang D, Wang W, et al. A novel coronavirus from patients with pneumonia in China, 2019. N Engl J Med. 2020;382:727-33.

4. Weinreich DM, Sivapalasingam S, Norton T, et al. REGN-COV2, a Neutralizing Antibody Cocktail, in Outpatients with Covid-19. N Engl J Med. 2021;384:3;238-51.

5. Allotey J, Stallings $\mathrm{E}$, Bonet $\mathrm{M}$, at al. Clinical manifestations, risk factors, and maternal and perinatal outcomes of coronavirus disease 2019 in pregnancy: living systematic review and meta-analysis. BMJ Open 2020;370:m3320. doi: 10.1136/bmj.m3320.

6. Yan H, Ding Y, Guo W. Mental health of pregnant and postpartum women during the coronavirus disease 2019 pandemic: a systematic review and meta-analysis. Front Psychol. 2020;11:617001.

7. POGI. Rekomendasi Penanganan Infeksi Virus Corona (Covid-19) pada maternal (hamil, bersalin dan nifas). Rev 2. Publikasi. 8 Agustus 2020.

8. WHO. COVID-19 Clinical menagement: Living Guidance, 25 January 2021. Geneva: World Health Organization. 2021.

9. Maertens K, Orije MRP, Van Damme P, Leuridan E. Vaccination during pregnancy: current and possible future recommendations. Eur J Pediatr. 2020; 179(2): 235-242. doi:10.1007/s00431-019-03563-w.

10. ESHRE. COVID-19 vaccination and assisted reproduction. Statement from the ESHRE COVID-19 Working Group .(https://www.eshre.eu/covid19). 